\title{
In-vitro Degradation Behaviour of Irradiated Bacterial Cellulose Membrane
}

\author{
D. Darwis ${ }^{* 1}$, T. Khusniya ${ }^{2}$, L. Hardiningsih ${ }^{1}$, F. Nurlidar ${ }^{1}$ and H. Winarno ${ }^{1}$ \\ ${ }^{I}$ Center for the Application of Isotope and Radiation Technology, National Nuclear Energy Agency \\ Jl. Lebak Bulus Raya, No. 49, Jakarta 12440, Indonesia \\ ${ }^{2}$ Department of Pharmacy, Pancasila University, Jakarta, Indonesia
}

\section{ARTICLE INFO}

Article history:

Received 05 December 2011

Received in Revised form 24 September 2012

Accepted 29 August 2012

Keywords:

Bacterial cellulose

Acetobacter xylinum

Guided bone regeneration

In vitro degradation

\begin{abstract}
A B S T R A C T
Bacterial cellulose membrane synthesized by Acetobacter xylinum in coconut water medium has potential application for Guided bone Regeneration. However, this membrane may not meet some application requirements due to its low biodegradation properties. In this paper, incorporation of gamma irradiation into the membrane is a developed strategy to increase its biodegradability properties. The in-vitro degradation study in synthetic body fluid (SBF) of the irradiated membrane has been analyzed during periods of 6 months by means of weight loss, mechanical properties and scanning electron microscopy observation compared to that the un-irradiated one. The result showed that weight loss of irradiated membrane with $25 \mathrm{kGy}$ and $50 \mathrm{kGy}$ and immersed in SBF solution for 6 months reached $18 \%$ and $25 \%$ respectively. While un-irradiated membrane did not give significant weight loss. Tensile strength of membranes decreases with increasing of irradiation dose and further decreases in tensile strength is observed when irradiated membrane was followed by immersion in SBF solution. Microscope electron image of cellulose membranes shows that un-irradiated bacterial cellulose membrane consists of dense ultrafine fibril network structures, while irradiation result in cleavage of fibrils network of cellulose. The fibrils network become loosely after irradiated membrane immersed in SBF solution due to released of small molecular weight carbohydrates formed during by irradiation from the structure.
\end{abstract}

(C) 2012 Atom Indonesia. All rights reserved

\section{INTRODUCTION}

Research on development of biodegradable polymers have a good promised in medical applications ranging from wound healing, guided bone regeneration membrane (GBR) and tissue regeneration $[1,2]$. GBR is the technique that uses a barrier membrane to prevent the appearance of epithelial migrations and connective tissue. The presence of connective tissue at the bone defect area prevents osteogenesis, consequently, incomplete healing frequently resulted. This technique also aimed to promote bone regeneration $[3,4]$. At present, there is two main types of barrier membranes used in GBR, non-bioabsorbable (resorbable) and bioabsorbable membranes. Expanded polytetrafluoroethylene (e-PTFE) membranes are the most widely studied non absorbable membrane for guided bone regeneration purposes. The excellent biocompatibility of e-PTFE

\footnotetext{
* Corresponding author.

E-mail address: darmawan_p3tir@batan.go.id
}

membranes has been confirmed by many studies, but it must be removed by a second surgical procedure, possible causing undesirable bone resorption, increases the risk of patient infection and other undesirable side effects $[5,6]$. Bioabsorbable membranes have been studied for similar kinds of indications as for PTFE membranes. Polyglycolide (PGA) is probably the most frequently studied bioabsorbable membrane. It has been studied in animal models, in cell culture experiments and even in clinical use [6]. Another absorbable membranes such as alginate, polylactic acid, polygalactin, and collagen were also been introduced for application in GBR procedure [1,3,7]. They do not require secondary surgery, furthermore, reduced cost, decreased tissues morbidity and limited risk of newly bone are the characteristics of bioabsorbable membranes [3].

Bacterial cellulose or microbial cellulose (BC), a polymer of glucose units linked together by (1-4)-glycosidic linkages, synthesized by Acetobacter xylinum has been used quite 
successfully in wound-healing application, providing that it could become a high value product in the field of biotechnology. $\mathrm{BC}$ membrane is characterized by a unique structure and properties such as high crystallinity (up to 90\%), high purity (free of hemicellulose and lignin), high mechanical properties and high degree of polymerization $[1,8]$. Because of the unique properties and high biocompatibility, for more than ten years, bacterial cellulose has been investigated and used in various clinical applications such as for wound care treatment and tissue engineering [8,9]. In vitro studies showed that regenerated bacterial cellulose hydrogels promotes bone cell attachment and proliferation and are very promising materials as a GBR/Guided bone Regeneration membrane for periodontal treatments [9]. However, it can not achieve bioabsorption in the human body because there is no chemical or enzyme process that can cleavage the $\beta-1,4$ glycosidic linkage and convert the crystalline cellulose fibrils into glucose [10]. Accordingly, the realization of in body degradation of cellulose hardly be achieves unless through the use of certain technique such as using ionizing radiation to cleavage glycosidic linkage of cellulose to become lower molecular weight or by using cellulose degrading enzyme (cellulase) $[10,11,12]$.

Ionizing radiation such as gamma rays and electron beam is widely used to modify polymer properties through crosslinking or degradation processes. Crosslinking results in increase mechanical properties, molecular weight, and reduce solubility of exposed polymer. On contrary, degradation results in low molecular weight, increases solubility and reduce mechanical properties [11]. Naturally occurring polymers or their derivatives including cellulose undergo chain scission reaction when irradiated by gamma or electron beam irradiation $[11,12,13]$. In our previous works, bacterial cellulose irradiated by gamma rays with dose up to $50 \mathrm{kGy}$ results in decrease in tensile strength and thermal properties indicating that degradation or chain cleavage was occurred [14].

The aim of this research is to develop biodegradable bacterial cellulose membrane by incorporation of gamma irradiation into the membrane. The in-vitro degradation study in synthetic body fluid (SBF) of the irradiated membrane has been analyzed during periods of 6 months by means of weight loss, mechanical properties and scanning electron microscopy observation compared to that the un-irradiated one.

\section{EXPERIMENTAL METHODS}

\section{Bacterial cellulose membrane preparation}

The coconut water based medium used for the inoculum had the composition $20 \%$ sucrose and $0.5 \%$ ammonium sulphate $\left(\left(\mathrm{NH}_{4}\right)_{2} \mathrm{SO}_{4}\right)$. The $\mathrm{pH}$ of the inoculum medium was adjusted using acetic acid glacial to $\mathrm{pH} 4$, then the inoculum medium was autoclave at $121^{\circ} \mathrm{C}$ for 10 minutes. The precultured medium contain Acetobacter xylinum was transfered aseptically into medium and incubated statically at $30 \pm 2^{\circ} \mathrm{C}$ for 8 days until the bacterial cellulose pellicle height was $\pm 1 \mathrm{~cm}$.

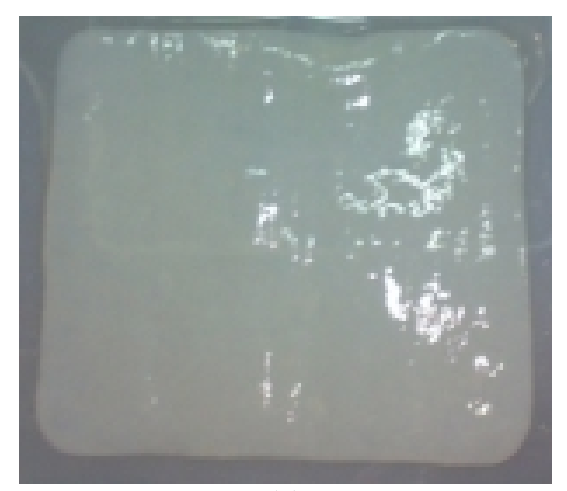

(a)

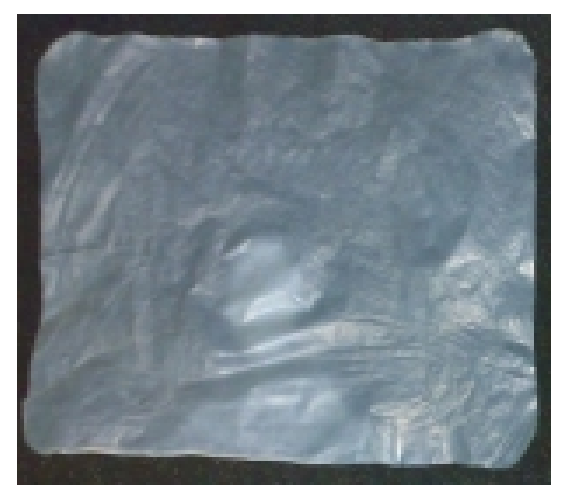

(b)

Fig. 1. Bacterial cellulose membrane (a). wet, (b). dried membrane.

The impurities of bacterial cellulose pellicle such as sucrose, bacteria and other interfering substances were eliminated by washing using sodium hydroxide, deionized water and hydrogen peroxide. At the first, pellicle was collected, rinsed with deionized water, followed with treated using 4\% sodium hydroxide at $90-95^{\circ} \mathrm{C}$ for 1 hour, and immersion in deionized water for 24 hours at room temperature to achieve a neutral $\mathrm{pH}$. After that, the pellicles were washed with $0.25 \%$ hydrogen peroxide at $40-45^{\circ} \mathrm{C}$ for 30 minutes, and followed with deionized water until the $\mathrm{H}_{2} \mathrm{O}_{2}$ concentration below 1000 ppm. 
The purified Bacterial cellulose pellicles were hand pressed and dried at room temperature for 24 hours until the water content was $\pm 5 \%$. The dried membrane (size $3 \mathrm{~cm} \times 3 \mathrm{~cm}$ ) were packed using PE plastic with triple packing and then irradiated using gamma irradiation at the dose 25 and $50 \mathrm{kGy}$ at the dose rate of $10 \mathrm{kGy} /$ hours.

\section{Biodegradation of the membranes}

Biodegradability of bacterial cellulose membrane was observed by immersion the membranes in Synthetic body fluid (SBF) during periods of 6 months. At the first, the irradiated bacterial cellulose membranes weighed and then immersed in Synthetic body Fluid (SBF). SBF solution was prepared with the same procedure reported by Cüneyt Tas, et al.[11], with composition: $6.547 \mathrm{~g} / \mathrm{L} \quad \mathrm{NaCl} ; 2.268 \mathrm{~g} / \mathrm{L} \mathrm{NaHCO}_{3}$, $0.373 \mathrm{~g} / \mathrm{L} \mathrm{KCl} ; 0.178 \mathrm{~g} / \mathrm{L} \mathrm{Na} \mathrm{Na}_{2} \mathrm{HPO}_{4} \cdot 2 \mathrm{H}_{2} \mathrm{O} ; 0.305$ $\mathrm{g} / \mathrm{L} \mathrm{MgCl}_{2} \cdot 6 \mathrm{H}_{2} \mathrm{O} ; 0.368 \mathrm{~g} / \mathrm{L} \mathrm{CaCl}_{2} \cdot 2 \mathrm{H}_{2} \mathrm{O} ; 0.071 \mathrm{~g} / \mathrm{L}$ $\mathrm{Na}_{2} \mathrm{SO}_{4}$ and $6.057 \mathrm{~g} / \mathrm{L}\left(\mathrm{CH}_{2} \mathrm{OH}\right)_{3} \mathrm{CNH}_{2}$, then the solution was adjusted into $\mathrm{pH} 7.4$ using $\mathrm{HCl} 1 \mathrm{M}$. The SBF solution was incubated at $37^{\circ} \mathrm{C}$ for $0,1,2$, 4 and 6 month. Biodegradation of Bacterial cellulose membranes were analysis using some parameters: weight loss, mechanical properties and Scanning electron microscopy (SEM) to study the structure and surface morphology of the membranes.

\section{Weight loss}

The weight of immersed membranes was determined after blotted drying on the membrane surfaces. The weight of immersed membrane were compared with the initial weight, the weight loss of the membranes were calculated using the following formula:

$$
\text { weight loss }(\%)=\frac{w_{i}-w_{f}}{w_{i}} \times 100 \%
$$

where $w_{i}$ and $w_{f}$ are the weight of initial and final immersed membrane.

\section{Mechanical properties}

Tensile strength of bacterial cellulose membranes were measured using Instron testing machine. The sample was dumbbell cut and run with crosshead speed of $25 \mathrm{~cm} /$ minute. The average tensile strength were calculated from 10 measurement samples.

\section{Scanning electron microscopy}

The surface morphologies of bacterial cellulose membranes were studied with Scanning Electron Microscopy (SEM).

\section{RESULTS AND DISCUSSION}

In our previous works [14], bacterial cellulose membrane was irradiated by gamma rays in order to improve its biodegradation in biological fluid. The results showed that tensile strength of membrane irradiated with 25 and $50 \mathrm{kGy}$ was decreased, significantly. It is indicated that molecular chain cleavage/degradation of cellulose was occurred during irradiation. It was also reported that gamma irradiated cotton cellulose at dose ranging from 0 to $130 \mathrm{kGy}$ under nitrogen or oxygen atmosphere resulted in degradation of cellulose to glucose, acetaldehyde, arrabinose, desoxy saccharide, glucoronic and gluconic acid, malon aldehyde and xylose [15]. To elaborate biodegradation of irradiated bacterial cellulose, the in-vitro degradation study using synthetic body fluid (SBF) of the irradiated membrane has been analyzed during periods of 6 months. Parameters analyzed were mechanical properties (tensile strength), weight loss, and surface morphologies performance by scanning electron microscopy. Un-irradiated (0 kGy) membrane was used as control

\section{Weight loss}

Biodegradability of bacterial cellulose membranes was measured by weight loss of membranes after immersion in SBF solution. The weight loss of the membranes after 1 to 6 month immersion were shown in Fig. 2. The result showed that weight loss of irradiated membrane increases with increasing of immersion time and irradiation doses. After 6 months immersion, the weight loss of irradiated membrane at 25 and $50 \mathrm{kGy}$ were about $18 \%$ and $26 \%$. While un-irradiated membrane did not shows any significant weight loss (less than $1 \%)$. From these results it can be said that irradiated bacterial cellulose membranes is easier to degraded in SBF solution. The weight loss is probably due to dissolved substances from degraded product of irradiated cellulose which is soluble in SBF solution such low molecular weight carbohydrates (glucose, arrabinose, desoxy saccharide), glucoronic and gluconic acid, Al-Masri et al. also reported that gamma irradiation successful in reducing fiber content, increase of sugar content and change of chemical composition or structure of product 
contain cellulose [16]. On the other hand, un-irradiated (control) bacterial cellulose membrane did not show significant weight loss, meaning that no degradation occur in SBF solution.

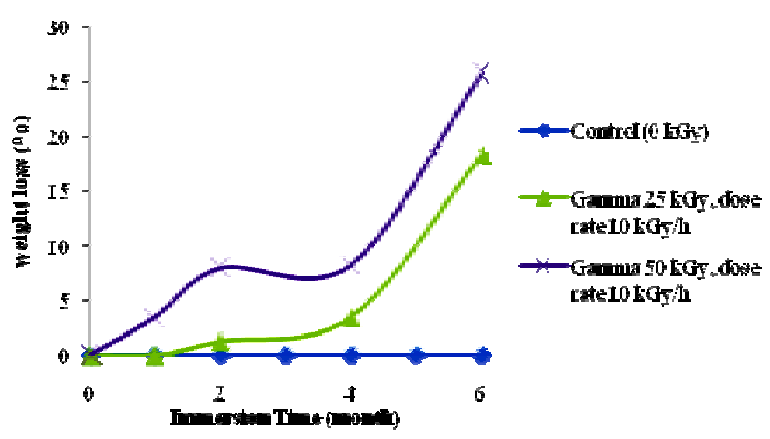

Fig. 2. Effect of gamma irradiation doses in weight loss of irradiated bacterial cellulose membrane after immersion in SBF solution.

\section{Mechanical properties}

The tensile strength of irradiated bacterial cellulose membranes before (0 month) and after immersion in SBF solution were presented in Table 1. It can be seen that tensile strength of un-irradiated (control), irradiated with $25 \mathrm{kGy}$ and $50 \mathrm{kGy}$ membranes before immersion in SBF solution were about 1395,820 and $720 \mathrm{kgf} / \mathrm{cm}^{2}$, respectively. The decrease in tensile strength is due to chain break of cellulose during irradiation. Increasing of irradiation dose resulted in more degradation. Aoki $T$ [17] reported that tensile strength of wood and cellulose decrease with increasing of irradiation dose, depending remarkably on loading mode. Furthermore, Blouin [18] reported that the major chemical effect produced by high energy radiation on cellulose were chain cleavages and formation of reducing and acid groups.

Table 1. Tensile strength $\left(\mathrm{kgf} / \mathrm{cm}^{2}\right)$ of irradiated bacterial cellulose membrane at the doses of 25 and $50 \mathrm{kGy}$ at the dose rate $10 \mathrm{kGy} /$ hours after immersion in SBF solution

\begin{tabular}{cccc}
\hline \multirow{2}{*}{$\begin{array}{c}\text { Immersion time } \\
(\text { month })\end{array}$} & \multicolumn{3}{c}{ Tensile strength $\left(\mathrm{kgf} / \mathrm{cm}^{2}\right)$} \\
\cline { 2 - 4 } & $0 \mathrm{kGy}$ & $25 \mathrm{kGy}$ & $50 \mathrm{kGy}$ \\
\hline 0 & 1395 & 820 & 720 \\
1 & 1390 & 401 & 378 \\
2 & 1392 & 117 & 49 \\
4 & 1387 & 36 & 36 \\
6 & 1386 & 0 & 0 \\
\hline
\end{tabular}

The result showed that there is no significant change in tensile strength of un-irradiated bacterial cellulose membrane, while the tensile strength of irradiated membrane decreased with an increase of immersion time. This phenomenon can be explained that the intermolecular hydrogen bonding of cellulose might be broken down or disrupted by irradiation and might reduce the crystallinity and mechanical strength of the membranes [19]. Further decreases in tensile strength after immersion in SBF solution probably due to the decline of fiber content and increase of dissolved sugar with the gamma irradiation[16].

\section{Structure of bacterial cellulose}

The structure of bacterial cellulose membranes were studied using SEM. Figure 3 shows an electron microscope image of (a) un-irradiated, (b) irradiated with $50 \mathrm{kGy,} \mathrm{(c)}$ irradiated with $50 \mathrm{kGy}$ and immersion in SBF for 4 months solution bacterial cellulose membranes.

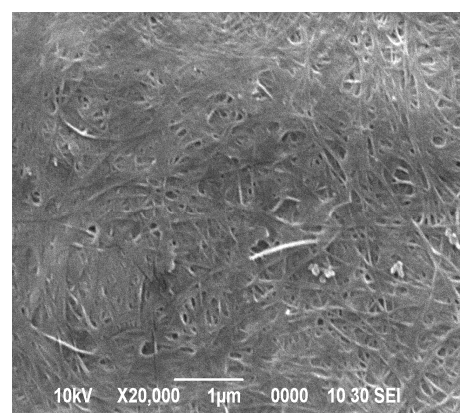

(a)

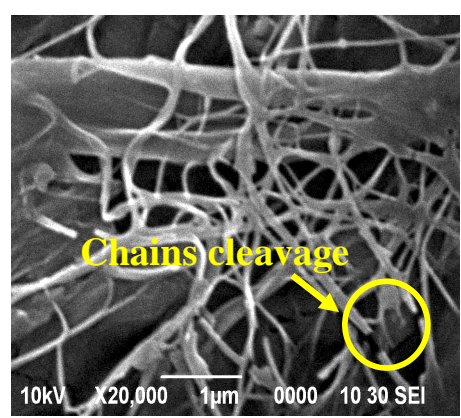

(b)

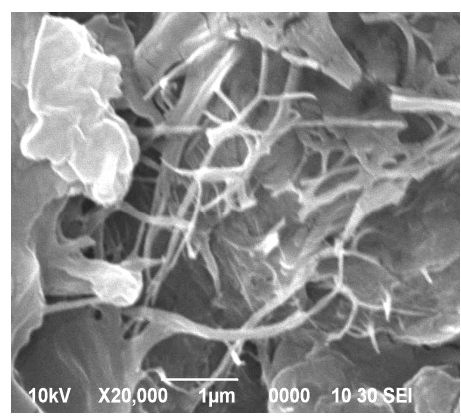

(c)

Fig. 3. SEM photographs of bacterial cellulose membrane: (a). Un-irradiated membrane, (b). Irradiated membrane with dose of $50 \mathrm{kGy}$ before immersion in SBF, (c). Irradiated membrane with dose of $50 \mathrm{kGy}$ after immersion in SBF for 4 months. 
Cellulose synthesis by Acetobacter is a complex process and involve the polymerization of single glucose residue into linier $\beta$-1,4-glucan chains, the extra cellular secretion of these linear chains, and the assembly and crystallization of the glucan chain into hierarchically composed ribbons. As a result of these processes, a three dimensional structure is formed [8]. Un-irradiated bacterial cellulose membrane consists of dense ultrafine fibril network structures. Irradiation result in cleavage of fibrils network of cellulose as shown in Fig. 3b. The fibrils network become loosely after membrane immersed in SBF solution due to released of small molecular weight carbohydrates formed during by irradiation from the structure as shown in Fig. 3c. This phenomenon is in agreement with weight loss and mechanical properties data.

\section{CONCLUSIONS}

From these experimental results, it can be concluded that gamma irradiation is an effective way to produce biodegradable bacterial cellulose by cleavages fibril network structure of cellulose. The weight loss of irradiated membrane after immersion in SBF solution for 6 months up to $25 \%$, and reduction of tensile strength of irradiated membranes were an evident of cellulose chain cleavage during irradiation. These results suggest that the membrane has a great potential for application in tissue engineering especially as guided bone regeneration membrane (GBR).

\section{ACKNOWLEDGEMENTS}

The authors are gratefully for the financial support from the Center for Application of Isotopes and Radiation Technology, National Nuclear Energy Agency, Indonesia.

\section{REFERENCES}

1. W. Czaja, A. Krystynowicz, S. Bielecki and R.M. Brown, Biomaterials 27 (2006)145.

2. I. Armentano, M. Dottori, E. Fortunati, S. Mattioli and J.M. Kenny, Biodegradable Polymer Matrix Nano Composites for Tissue
Engineering, in: A Review, Polymer Degradation and Stability (2010) 2126.

3. Y. Ueyama, K. Ishikawa, T. Mano, T. Koyama, H. Nagatsuka, K. Suzuki and at al., Biomaterials 23 (2002) 2027.

4. C. Xianmiao, L. Yubao, Z. Yi, Z. Li, L. Jidong and W. Huanan, Materials Science and Engineering C 29 (2009) 29.

5. A. Piattelli, A. Scarano, P. Russo and S. Matarasso, Biomaterials 17 (1996) 791.

6. M. Kollomaki, H. Niiranen, K. Puumanen, N. Ashammakhi, T. Waris and P. Tormala, Biomaterials 21 (2000) 2495.

7. A. Kasaj, et al., Head \& Face Medicine 4, 22 (2008) 1.

8. W.K. Czaja, D.J. Young, M. Kawecki and R.M. Brown, Biomacromolecules 8 (2007) 1.

9. Mendes, N. Péricles, et al., Acta Veterinaria Scandinavica 51 (2009) 12.

10. Y. Hu, J.M. Catchmark, Acta Biomaterial (2011). doi:10.1016/j.actbio.2011.03.028 (in press).

11. A.J. Chmielewski, Wordwide Developments in the Field of Radiation Processing of Materials in the Down of $21^{\text {st }}$ Century, Proceeding Nucleonika 51 (supplement 1) (2006) S3.

12. C.M. Foldvary, E. Takacs, Radiat, Phys. Chem. 67 (2003) 505.

13. YeP. Petryayev, V.V. Boltremeyuk, N.I. Kovalenko and N.I. Syadiro, Polymer Scien. USSR 30 (1988) 2208.

14. D. Darwis, A Scientic Journal for the Application of Isotopes and Radiation 5 (2009) 83. (in Indonesian).

15. R. Bludovsky, M. Prochazka and J. Kopoldove, J. Radioanal. Nucl. Chem. Letter 87 (1984) 69.

16. M.R. Al-Masri and K.D. Guenther, Radiat. Phys. Chem. 55 (1999) 323.

17. T. Aoki and M. Norimoto, Wood Research 62 (1977) 19.

18. F.A. Blouin and JET C. Arthur, J. Chem. Engine. Data 5 (1960) 470.

19. Y. Zheng, Z. Pan and R. Zhang, Int. J. Agric. Biol. Eng. 2 (2009) 51. 